\title{
Prospective observation of breast/ovarian cancer risk in BRCA1 carriers depending on serum selenium level optimized with diet
}

\author{
J Lubiński*, T Huzarski, A Jakubowska, J Gronwald, K Jaworska, M Muszyńska, G Sukiennicki, K Durda, C Cybulski, \\ T Dębniak, A Tołoczko, O Oszurek, P Serrano-Fernandez, R Scott, S Narod
}

From Annual Conference on Hereditary Cancers 2010

Szczecin, Poland. 10-11 December 2010

The aim of the study is to observe prospectively the possibility of lowering the cancer risk among BRCA1 carriers by optimizing selenium concentration in diet/ organism. Results of studies performed in several centres, particularly of our own search, are strongly indicating on potential of decreasing breast/ovarian cancer risk among carriers by optimization of selenium concentration in the body. Studies will be performed on group of 1500 BRCA1 carriers. Cohort will be recruited during the first 6 months of the project. Mean length of follow-up will be 3 yrs. From all females serum will be collected for selenium analysesat the beginning and, then, every 6 months. Participants will receive the list of products with selenium concentration estimated according to literature data and, additionally, information about e-store (http:// www.dietaantyrakowa.pl) specialized in distribution of food products with defined amount of selenium. Information on optimal selenium concentration according to existing data will be provided also. It is expected that among $\sim 750$ carriers following recommended diet changes 38 cancers will be diagnosed and among the others $~ 750-60$. The difference between groups will be statistically significant with $p=0.0278$. If necessary, investigation will be extended.

Published: 12 January 2012

* Correspondence: lubinski@sci.pam.szczecin.p

International Hereditary Cancer Center, Pomeranian Medical University, Szczecin, Poland

Submit your next manuscript to BioMed Central and take full advantage of:

- Convenient online submission

- Thorough peer review

- No space constraints or color figure charges

- Immediate publication on acceptance

- Inclusion in PubMed, CAS, Scopus and Google Scholar

- Research which is freely available for redistribution 